Carola Trips

English Syntax in Three Dimensions 



\section{Carola Trips}

\section{English Syntax in \\ Three Dimensions}

History - Synchrony - Diachrony 
ISBN 978-3-11-028984-8

e-ISBN (PDF) 978-3-11-029009-7

e-ISBN (EPUB) 978-3-11-039514-3

Library of Congress Cataloging-in-Publication Data

A CIP catalog record for this book has been applied for at the Library of Congress.

Bibliographic information published by the Deutsche Nationalbibliothek

The Deutsche Nationalbibliothek lists this publication in the Deutsche Nationalbibliografie; detailed bibliographic data are available on the Internet at http://dnb.dnb.de.

(C) 2015 Walter de Gruyter GmbH, Berlin/Boston

Cover image: Silvio Verrecchia/iStock/thinkstock

Printing and binding: CPI books $\mathrm{GmbH}$, Leck

@ Printed on acid-free paper

Printed in Germany

www.degruyter.com 
To Ian and Sten, two great teachers 
